\begin{tabular}{|c|c|c|c|}
\hline \multirow{3}{*}{$\begin{array}{r}\text { Case Reports in } \\
\text { Gastroenterology }\end{array}$} & \multirow{2}{*}{\multicolumn{2}{|c|}{ Case Rep Gastroenterol 2020;14:1-6 }} & \multirow[b]{3}{*}{$\begin{array}{l}\text { Karger } \\
\text { Open access }\end{array}$} \\
\hline & & & \\
\hline & $\begin{array}{l}\text { DOI: } 10.1159 / 000505228 \\
\text { Published online: January 3, } 2020\end{array}$ & $\begin{array}{l}\text { (c) } 2020 \text { The Author(s) } \\
\text { Published by S. Karger AG, Basel } \\
\text { www.karger.com/crg }\end{array}$ & \\
\hline & $\begin{array}{l}\text { This article is licensed under th } \\
\text { International License (CC BY-NC) } \\
\text { Usage and distribution for comme }\end{array}$ & $\begin{array}{l}\text { mons Attribution-NonCommercial } 4.0 \\
\text { rger.com/Services/OpenAccessLicense). } \\
\text { quires written permission. }\end{array}$ & \\
\hline
\end{tabular}

\title{
Early Postendoscopic Transverse Colo-Colonic Intussusception
}

\author{
Harry He ${ }^{a}$ Vikashsingh Rambhujun ${ }^{a}$ Matthew DeMaria ${ }^{a}$ \\ Mohammad Alic Raluca Vrabie ${ }^{\mathrm{b}}$ \\ aDepartment of Medicine, NYU Winthrop University Hospital, Mineola, NY, USA; \\ ${ }^{b}$ Department of Gastroenterology, NYU Winthrop University Hospital, Mineola, NY, USA; \\ 'Gastroenterology and Hepatology, Guthrie Cortland Medical Center, Cortland, NY, USA
}

\section{Keywords}

Abdominal pain · Bowel obstruction - Colonoscopy · Endoscopy · Gastrointestinal tract · Intussusception

\begin{abstract}
Intussusception is defined as telescoping of the proximal bowel (intussusceptum) into the lumen of the distal bowel, otherwise called the intussuscipiens. While it is one of the most common causes of intestinal obstruction in children between the ages of 3 months and 6 years, intussusception accounts for about $1 \%$ of such cases in adults. Intussusception is idiopathic in 8-20\% of patients and most commonly occurs in the small intestines in adults. We describe the unique case of a colo-colonic intussusception in a 54-year-old female patient 1 week after a colonoscopy for suspected inflammatory bowel disease. The discussion focuses on the presentation and management options of intussusception.

(C) 2020 The Author(s) Published by S. Karger AG, Basel
\end{abstract}

\section{Introduction}

Intussusception is a form of bowel obstruction defined as telescoping of proximal segment of bowel into a distal segment of bowel [1]. This condition mostly commonly presents in the pediatric population, where it is usually benign and spontaneous, and most patients are treated successfully with enemas. Intussusception in the adult population only accounts for 
$5 \%$ of all cases of the disease and is usually secondary to a lead point such as a tumor, polyps, or diverticuli in addition to impaired peristalsis. It is most likely to occur in the confluences of a freely moving segment of bowel and a fixed segment. There are four types of intussusception: entero-enteric (entirely confined to small bowel), colo-colic (entirely confined to large bowel), ileo-colic (terminal ileum prolapsing into the ascending colon), and ileo-cecal, where the ileo-cecal valve is the lead point.

Intussusception in adults presents with nonspecific gastrointestinal symptoms such as nausea, vomiting, abdominal pain, bloody bowel movements, or constipation. Cases in whom organic lesions act as the lead point classically present as bowel obstruction. The most sensitive diagnostic test for this disease is CT, which can identify location, surrounding tissue, and presence or absence of a lead point. Since adults who present with intussusception often do have a lead point that can cause obstruction and ischemia, surgery is classically the primary treatment. However, cases without a physical lead point usually resolve spontaneously [2].

Intussusception developing after an endoscopic procedure is an extremely rare occurrence and there have only been a handful of case reports about it. In several cases a polypectomy was performed, and the subsequent intussusception was attributed to bowel edema acting as a lead point. All cases were treated with surgical intervention [3-5].

\section{Case Report}

A 54-year-old female patient with a past medical history significant for diabetes presented to the emergency department with worsening abdominal pain. The day before she underwent a diagnostic colonoscopy for complaints of chronic diarrhea (2 months) where a transverse colon adenomatous polyp was resected, and several mucosal biopsies were obtained.

The patient reported that the abdominal pain started suddenly about $4-5 \mathrm{~h}$ after the colonoscopy. She described the pain as being colicky and intermittent, occurring every hour, lasting for about $15 \mathrm{~min}$, and then resolving on its own. She reported that overnight the pain worsened to the point that she sought medical care the next morning when we (the gastrointestinal team) were consulted by the emergency department. Additionally, she noticed that she had some red mucus in her stools on the morning of presentation.

Her vital signs in the emergency department were stable with a blood pressure of 128/ $72 \mathrm{~mm} \mathrm{Hg}$, a pulse of $83 \mathrm{bpm}$, and a respiratory rate of $16 / \mathrm{min}$ with normal oxygen saturation. Physical examination showed a nondistended abdomen, with mild tenderness over the right upper quadrant without any palpable masses. Her blood work was significant for a white cell count of 13, lactate of 1.2, and a normal metabolic profile.

In the emergency department, the patient had an abdominal X-ray, and a CT of the abdomen with intravenous contrast which showed a transverse colo-colonic intussusception (Fig. 1, 2, 3) with partial obstruction.

The patient was seen by the surgical team who deemed her not to be obstructed and opted for conservative management with intravenous fluids and nil per os. On the following day, the patient reported that her symptoms had rapidly improved and subsequently had an abdominal X-ray that showed spontaneous resolution of her intussusception (Fig. 4). She was started on a liquid diet which was advanced without any complications. She was discharged on the third day of stay after she had had a normal bowel movement. She followed up with her gastroenterologist who ordered an MRI 2 months after discharge, which was unremarkable (Fig. 5). 


\section{Discussion}

Intussusception is a rare cause of bowel obstruction in adults, accounting for approximately $1 \%$ of all cases [3]. Since malignancy accounts for almost half of these cases, colonoscopy as an etiology is very uncommon [6]. Only 5 cases of post colonoscopy intussusception have been reported in the literature. Two of these patients had polyp removal as part of the screening protocol/colonoscopy [4, 7], two presented with diarrhea and normal colonoscopy findings [5], and the last had chronic constipation and pain in the setting of a prior history of low anterior resection for endometriosis [8]. All of them presented with abdominal pain shortly after colonoscopy and CT findings revealed intussusception.

The proposed theories regarding causative factors for intussusception include polypectomy sites as lead points, mucosal edema and insufflation causing hyperperistalsis, and prior surgeries. In our patient, polypectomy in the setting of colitis likely contributed to her development of an intussusception and partial bowel obstruction after colonoscopy.

Although complete resection is commonly performed in cases with malignancy and reduction (with air insufflation versus barium enema) recommended in those without, there are no standard guidelines for management. In all the colonoscopy-related cases cited, surgical interventions were pursued; however, in our case we opted for conservative management initially, with consideration of surgery if there was no symptomatic improvement. Our patient had complete resolution of her symptoms and was discharged without any invasive intervention.

This report demonstrates that in nonmalignant intussusception cases a conservative approach at first, with surgery reserved for patients with worsening symptoms, is probably practical.

Intussusception in adults is rare and post colonoscopy intussusception is even more uncommon. This explains why there is little consensus regarding the management of these patients. Current management encourages colectomy if malignancy is found or suspected and/or there is concern for bowel ischemia, but for nonmalignant cases, e.g., post colonoscopy intussusception, a conservative approach first may prevent major surgery.

\section{Acknowledgements}

We would like to thank the NYU Winthrop University Hospital Department of Medicine for supporting our research in this case report. We would also like to thank the NYU Winthrop University Hospital Department of Radiology for providing us with interpretation and insight into the radiological images included in this case report.

\section{Statement of Ethics}

The patient gave her informed consent for this report to be written and for its contents along with the images to be published. 


\section{Disclosure Statement}

The authors certify that they have no affiliations with or involvement in any organization or entity with any financial interest (such as honoraria; educational grants; participation in speakers' bureaus; membership, employment, consultancies, stock ownership, or other equity interest; and expert testimony or patent-licensing arrangements) or nonfinancial interest (such as personal or professional relationships, affiliations, knowledge or beliefs) in the subject matter or materials discussed in this paper.

\section{Funding Sources}

The authors would like to thank NYU Winthrop University Hospital for providing funding for the publishing of this article.

\section{Author Contributions}

H. He, V. Rambhujun, and M. DeMaria assisted in literature review and writing of the manuscript. M. Ali and R. Vrabie assisted in reviewing and final proofreading of the manuscript as well as providing mentorship. H. He is the guarantor of submission.

\section{References}

1 Waseem M, Rosenberg HK. Intussusception. Pediatr Emerg Care. 2008 Nov;24(11):793-800.

2 Marinis A, Yiallourou A, Samanides L, Dafnios N, Anastasopoulos G, Vassiliou I, et al. Intussusception of the bowel in adults: a review. World J Gastroenterol. 2009 Jan;15(4):407-11.

3 Wilson A, Elias G, Dupiton R. Adult colocolic intussusception and literature review. Case Rep Gastroenterol. 2013 Sep;7(3):381-7.

4 Ho MM, Park JJ, Prasad LM. Post Colonoscopy Colonic Intussusception Reduced via a Laparoscopic Approach. JSLS. 2010 Oct-Dec;14(4):596-9.

5 Nachnani J, Burns E, Margolin D, Clarkston WK. Colocolonic intussusception after colonoscopy. Gastrointest Endosc. 2012 Jan;75(1):223-5.

6 Azar T, Berger DL. Adult intussusception. Ann Surg. 1997 Aug;226(2):134-8.

7 Yamazaki T, Okamoto H, Suda T, Sakai Y, Hatakeyama K, Hokari I, et al. Intussusception in an adult after colonoscopy. Gastrointest Endosc. 2000 Mar;51(3):356-7.

8 Min MX, Sklow B, Vaughn BP. Intussusception after Routine Colonoscopy: A Rare Complication. ACG Case Rep J. 2017 Apr;4(1):e63. 


\section{Case Reports in Gastroenterology}

\begin{tabular}{l|l}
\hline Case Rep Gastroenterol 2020;14:1-6 \\
\hline DOI: 10.1159/000505228 & $\begin{array}{l}\text { @ } 2020 \text { The Author(s). Published by S. Karger AG, Basel } \\
\text { www.karger.com/crg }\end{array}$ \\
\hline
\end{tabular}

He et al.: Early Postendoscopic Transverse Colo-Colonic Intussusception

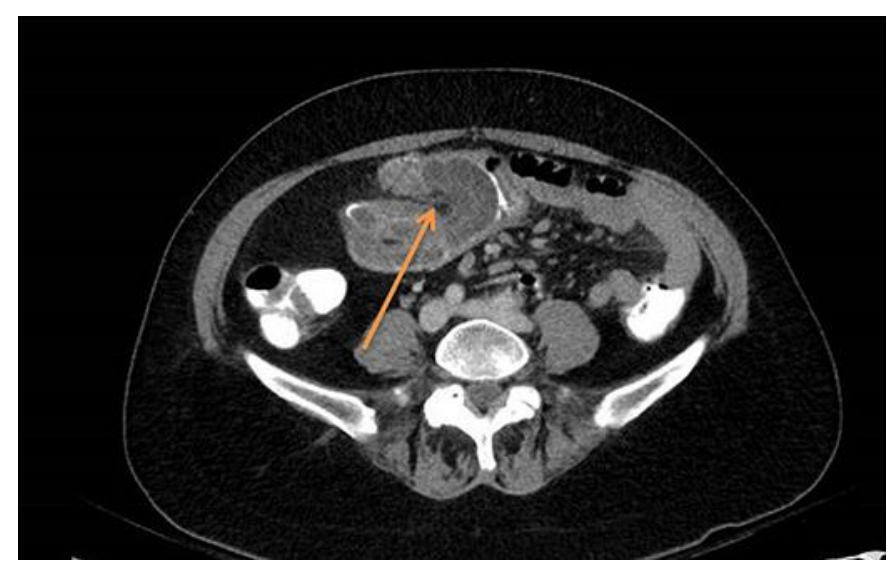

Fig. 1. Intussusception on CT (arrow).

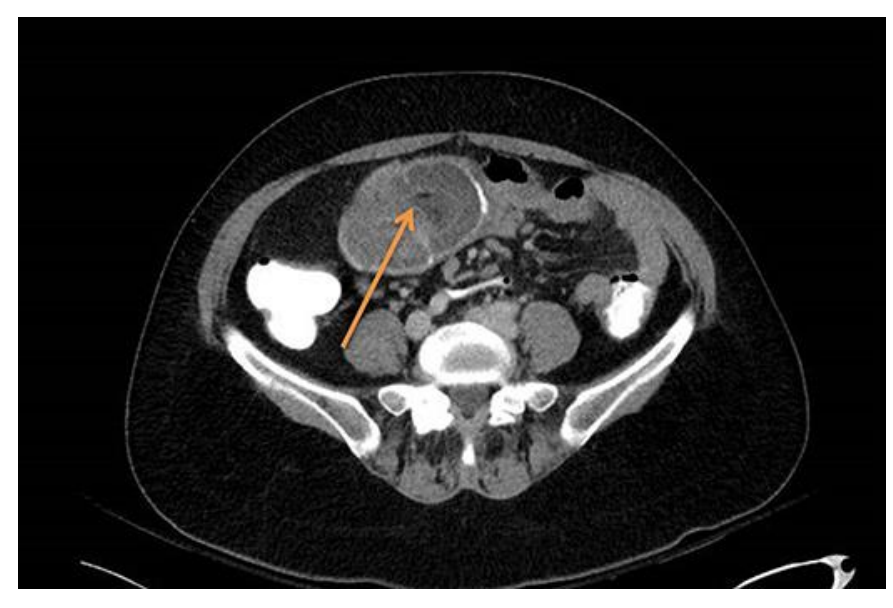

Fig. 2. Extension of the intussusception (arrow).

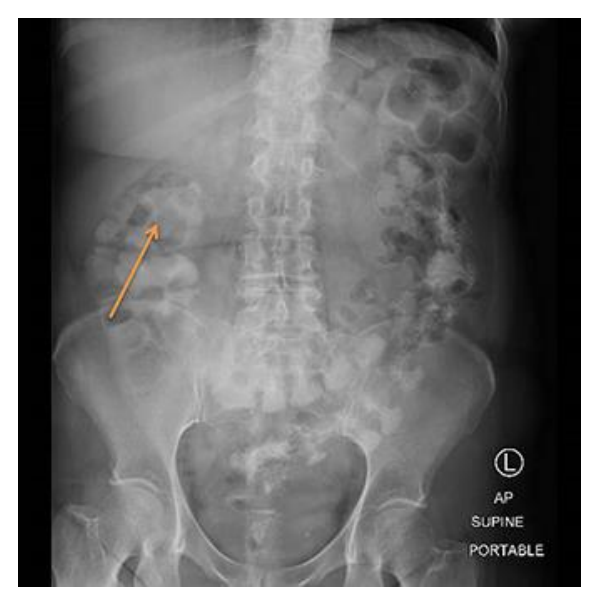

Fig. 3. X-ray on admission showing the intussusception (arrow). 


\section{Case Reports in Gastroenterology}

\begin{tabular}{l|l}
\hline Case Rep Gastroenterol 2020;14:1-6 \\
\hline DOI: 10.1159/000505228 & $\begin{array}{l}\odot \text { 2020 The Author(s). Published by S. Karger AG, Basel } \\
\text { www.karger.com/crg }\end{array}$ \\
\hline
\end{tabular}

He et al.: Early Postendoscopic Transverse Colo-Colonic Intussusception

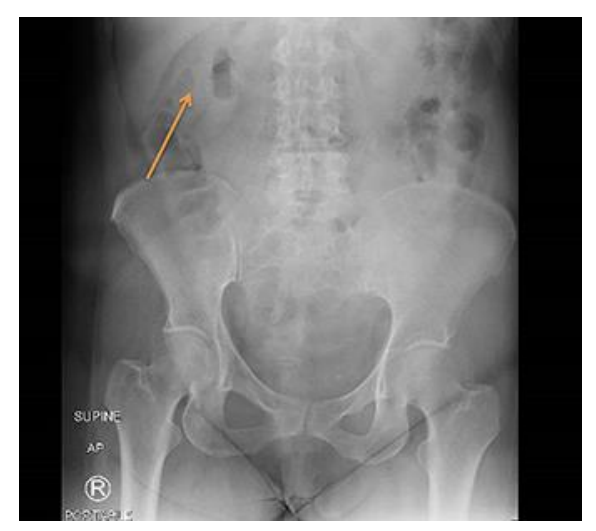

Fig. 4. X-ray showing resolution intussusception (arrow).

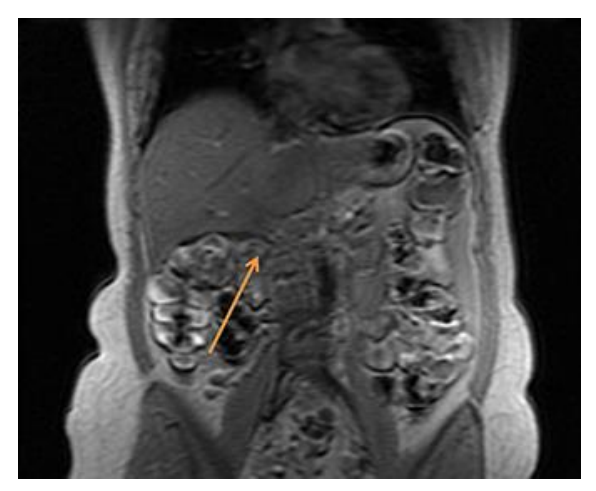

Fig. 5. Interval MRI showing resolution of intussusception (arrow). 